\title{
A GUERRA DOS EDULCORANTES
}

Tal como a linha de montagem e o desenvolvimento da tecnologia industrial do fim do século XIX transformaram de tal modo a vida da humanidade, que deram origem à chamada era industrial, estamos actualmente a sentir já no dia a dia, as consequências de uma nova era, confusamente imbricada na primeira que, a pouco e pouco, vai transformando em múltiplas facetas o nosso quotidiano. Ê a aurora de um novo periodo, a era do marketing.

Não a caracteriza uma nova ferramenta nem um novo know bow, apenas uma nova mentalidade: a de criar processos novos que permitam vender uma ideia, que outros, muitos outros, se possível todos os outros - supremo ideal - queiram comprar. Esta mentalidade que à partida era meramente comercial vai, a pouco e pouco, invadindo os campos da indústria, dos serviços, da arte, da política...

Que foi senão uma técnica de puro marketing político, magistralmente desenvolvida por homens geniais como Goebels que conseguiu em poucos anos, que uma ideia nascida numa obscura cervejaria de Munique, fosse assimilada por uma nação e aspirasse a conquistar um planeta, por acaso, o nosso!...

$\mathrm{Na}$ profissão médica, a mentalidade da nova era vai, a pouco e pouco e insidiosamente influenciando os nossos actos.

Vêm estes comentários a propósito de mais uma batalha na frente dos edulcorantes, na guerra económica que os grandes empórios da indústria farmacêutica travam a nível mundial.

Porque na mentalidade do marketing, 'cada vez mais agressiva, já não basta vender bem a sura ideia, o seu produto, pode tornar-se necessário esmagar a concorrência sé possível, aniquilá-la. Para isso, todos os meios são bons, todas as oportunidades aproveitadas e exploradas.

O terreno da manobra é o ideal : é a opiniāo pública ignorante, acrítica, poderosa mas sem perspectiva. Que se expressa pelo mesmos meios que a influenciam - os órgãos de informação - os mass media que são, ao mesmo tempo, controlados ou influenciados pelas grandes potências económicas em luta.

As armas são fornecidas pela miriade dos investigadores profissionais ou potenciais, sempre ávidos de bolsas, de grants, de benesses.

Com essas armas procura-se sensibilizar a opinião pública mundial átravés de campanhas de imprensa e, com elas, forçar as instituições estatais de saúde a aniquilar o adversário.

A guerra dos edulcorantes começou ém 1969 quando o Sr. Robert Finch, Secretário de Estado da Saúde dos E.U.A. anunciou a retirada dos ciclamatos da lista de produtos classificados como inócuos (Jukes 1976). O estudo, quo motivou esta decisão, 
tinha. sido conduzido durante dois anos em ratos que recebiam na alimentação uma mistura a 10:1 de ciclamato de sódio e sacarina, na dose de $2500 \mathrm{mg}$ por $\mathrm{Kg}$ de peso, tendo-se verificado o aparecimento de carcinoma da bexiga nalguns animais. Com base neste estudo, realizado com doses maciças de uma mistura de dois edulcorantes, em animais com uma alta incidência de tumores expontâneos, decidiu-se retirar do mercado apenas um dos dois produtos em causa, com o argumento que o outro - a sacarina já era usado desde há muito sem terem sido detectadas potencialidades cancerígenas.

O ef eito principal desta decisão foi o descrédito que caiu sobre as instituições com obrigação de velar pela saúde pública. Os consumidores americanos tinham tido a garantia dada e confirmada pela indústria, pela F.D.A. e pela National Academy of Sciences, que os ciclamatos eram inócuos. $\mathrm{E}$, de repente, com base numa única experiência de evidência duvidosa, vinha afirmar-se que os ciclamatos podiam ser cancerígenos. O descrédito público estendeu-se dos regulamentos da Food and Drug Administration americana à própria indústria e ciência que tinharn sido incapazes de detectar este efeito nos 13 anos que tinham decorrido entre a descoberta do ciclamato em 1937 e o seu lançamento no mercado em 1950, tal como tinham sido ineficientes em demonstrar este efeito cancerígeno no período entre 1950 e 1968 , em que o uso dos ciclamatos tinha crescido progressivamente.

Retirados das farmácias e das bebidas refrigerantes, em que eram usados como aditivos, os ciclamatos iniciaram um longo período de interdição, não só nos E.U.A. como na maioria dos países ocidentais que seguiram esta atitude, apesar de múltiplos relatórios e trabalhos terem chegado a conclusões contrárias, apesar do bom senso de muitas críticas e opiniões abalizadas.

O problema estava quase esquecido quando um recente trabalho de Howe et al (1977) do National Cancer Institute of Canada, veio de novo alertar a opinião pública, pondo desta vez em causa o decano dos edulcorantes, a venerável sacarina. Com um estudo feito em 480 homens e 152 mulheres que sofriam de carcinoma da bexiga e outros tantos casos escolhidos para controlo, este autor afirmou haver uma relação positiva entre o risco para este tumor e o uso de sacarina.

O grupo controlo e o grupo carcinoma tinha, além dum diferente consumo de sacarina exclusivamente nos homens, diferente exposição a pelo menos dois outros factores apontados como passiveis agentes cancerígenos para tumores de bexiga: o consumo de tabaco e de café solúvel. Comentadores destacados saíram a fazer a crítica e a apontar os pontos fracos do artigo (Leading article 1977) e outros trabalhos na espécie humana chegaram a conclusões contrárias (Kessler 1976; Morgan et al 1974; Wyndor e Goldsmith 1977).

Tarde demais. Com o complexo de culpa típico dos políticos com funções de controlo de saúde, o governo canadiano proibiu imediatamente o uso da sacarina, adiando apenas esta interdição de alguns meses para dar tempo a reintroduzir os ciclamatos reabilitados (World Markets 1978).

Esta era a verdade oficial canadiana. Porque um pouco mais a sul, a verdade E.U.A. era exactamente inversa. O mesmo maniqueismo farmacológico mas de sinal contrário. A poderosa F.D.A. mantinha a interdição aos ciclamatos e a permissão à sacarina.

Em toda esta guerra não é porém este ou aquele produto ou os seu fabricantes que são vencidos e vencedores. Porque os grandes derrotados são os cientistas, os investigadores pela imensa onda de descrédito que todos estes factos acabam por gerar.

Nesta guerra económica o único factor científico indiscutivel é a ocorrência de um tumor. Neste caso particular, um tumor do urotélio ou epitélio que forra o aparelho 
excretor urinário, cuja ocorrência depende de 4 factores principais (Ferreira 1977): 1. Susceptibilidade; 2. Factor tempo; 3. Existência de lesões pré-cancerosas; 4. Um agente carcinogénico. Ora os tumores do urotélio são frequentemente múltiplos, sugerindo uma origem multifocal. São frequentes as lesões pré-cancerosas (papilomas etc.) e há uma susceptibilidade individual que é considerada por muitos o factor decisivo no desenvolvimento tumoral. Há substâncias comprovadamente cancerígenas como a B-naftilamina e a xenilamina e alguns amino-fenóis excretados nas urinas normais que poderiam igualmente estar em causa.

Mas embora todos estes aspectos sejam conhecidos, desconhece-se a verdadeira razâo que leva um papiloma vesical benigno a transformar-se em carcinoma papilar, quando para muitos autores a diferença é apenas de grau (Ferreira 1977). Este último aspecto, por exemplo é altamente perturbante e difícil de concebr à luz dos conhecimentos actuais, pois é difícil compreender que uma variável de natureza discontínua como a qualidade de ser ou não ser carcinoma, se possa adquirir como uma variável contínua sem hiatos de transição.

Se os edulcorantes actuais - ciclamatos ou sacarina - podem ajudar a esta transformação e ser assim agentes cancerígenos é uma pergunta que nos parece ainda precoce, no momento científico actual. Quase tudo são incógnitas neste campo e os mecanismos essenciais de transformação são ainda desconhecidos. Tentar responder-lhe tem o risco de tomar o fumo pelo fogo, a sombra em vez do objecto. Mais do que descobertas sensacionais e apressadas interessam-nos para o progresso da ciência caminhos seguros e racionais.

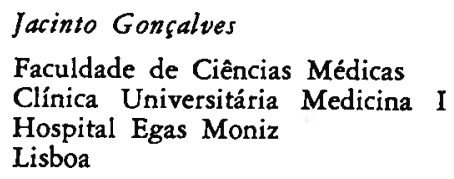

\section{BIBLIOGRAFIA}

FERREIRA AM: Urologia, Noções fundamentais, 3." ed. Lisboa. Ed. A. M. Ferreira, H. C. L. p. 293, 1977.

FRIEDMAN L, RICHARDSON HL, RICHARDSON ME, LETHCO EJ, WALLACE WC, SAURO FM: Toxic Response of rats to cyclamates in chow and semisynthetic diets. $J$ Natl Cancer Inst 49: 751, 1972.

HOWE GR, BURCH JD, MILLER AB: Artificial sweeteners and human bladder cancer. Lancet 2: 578, 1977.

JUKES TH: Cyclamate sweeteners. JAMA, 236: 1987, 1976.

KESSLER II: Baltimore Study of 1038 cases. I Urol 115: 143, 1976.

LEADING Article: Bladder Cancer and Saccharin. Lancet 2: 592, 1977.

MORGAN RW, JAIN M: (citado em 6) Can Med Assoc J 111: 1067, 1974.

WYNDER EL, GOLDSMITH R: (citado em 3) Cancer 40: 1246, 1977.

World Market: Scrip, October 21: 22, 1978.

Pedido de Separatas: Jacinto Gonçalves

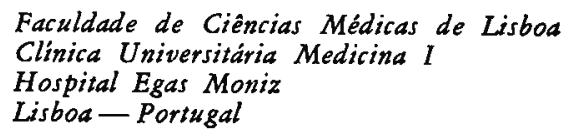

